\title{
Design of PHEMA Cryogel as Bioreactor for Biological Cyanide Degradation from Wastewater
}

\author{
Atıksulardan Biyolojik Siyanür Yıkımı İçin Biyoreaktör Olarak \\ PHEMA Kriyojellerin Tasarımı
}

\author{
Research Article \\ Sevgi Aslıyüce, Adil Denizli* \\ Department of Chemistry, Hacettepe University, Ankara, Turkey.
}

\section{A B S TR ACT}

\begin{abstract}
Cyan yanide is a hazardous substance and a toxic contaminant. It is found in the environment as a natural product of industrial activities. Biological methods are an alternative and promising potential approach to the conversion and destruction of toxic by products that can be formed by both cyanide and chemical treatment. It is known that a lot of fungi, bacteria and some plants are used in biological treatment works. Trichoderma is a genus of fungi that has enzymes for cyanide destruction. It is known that, under aerobic conditions, cyanide can be converted to ammonia by microbial activity and then nitrate by oxidation. Cryogels are gel networks synthesized at temperatures below zero using monomeric or polymeric precursors. Polymeric network occurs while water (i.e solvent) forms ice crystals. After the ice crystals melt, polymeric network with large pores are formed. Cryogels are used in a variety of areas of biotechnology, including chromatographic materials, carriers for immobilization of biomolecules and cells. In this study, poly(2-hydroxyethyl methacrylate) (PHEMA)-based Triccoderma spp. embedded supermacroporous cryogels were synthesized for cyanide destruction. The prepared polymeric materials were tested for cyanide degradation at different $\mathrm{pH}$, temperature and initial concentrations to examine their suitability for this purpose.
\end{abstract}

\section{Key Words}

Biological degradation, cryogels, Triccoderma spp., cyanide, poly(2-hydroxyethyl methacrylate).

\section{öz}

\begin{abstract}
Siyanür, tehlikeli bir madde ve zehirli bir kirleticidir; ancak, endüstriyel faaliyetlerin doğal bir ürünü olarak $S$ çevrede bulunur. Biyolojik yöntemler hem siyanür hem de kimyasal süreçlerde ortaya çıkan zehirli yan ürünlerin zararsız ürünlere dönüştürülmesine ve bozunmasının alternatif bir potansiyel yaklaşımdır. Biyolojik arıtma işlemlerinde birçok mantar, bakteri ve bazı bitkilerin kullanıldığı bilinmektedir. Trichoderma spp., siyanür tahribatı için enzimler üreten bir mantar türüdür. Aerobik koşullar altında mikrobiyal aktivite sonucunda siyanürün oksidasyon ile amonyak ve daha sonra nitrata dönüşebileceği bilinmektedir. Kriyojeller, monomerik veya polimerik öncülleri kullanarak sıfırın altındaki sıcaklıklarda sentezlenen jel matrisleridir. Polimer ağı, çözücü (su) buz kristalleri oluşumu ile gerçekleşir. Buz kristallerinin erimesinden sonra, büyük gözenekli polimerik matrisler oluşur. Kriyojeller, kromatografik malzemeler, moleküllerin ve hücrelerin immobilizasyonu için taşıyıcılar gibi biyoteknolojinin çeşitli alanlarında kullanılır. Bu çalışmada siyanür bozunması için poli(2hidroksietil metakrilat) (PHEMA) bazlı, Trichoderma spp. gömülü kriyojeller sentezlenmiştir. Hazırlanan polimerik malzemelerin uygun olup olmadığını belirlemek için farklı pH, sıcaklık ve başlangıç derişimlerinde siyanür bozunması test edilmiştir.
\end{abstract}

\section{Anahtar Kelimeler}

Biyolojik yıkım, kriyojeller, Triccoderma spp., siyanür, poli(2-hidroksietil metakrilat).

Article History: Received: June 21, 2017; Revised: Aug 10, 2017; Accepted: Oct 12, 2017; Available Online: Dec $25,2017$.

DOI: 10.15671/HJBC.2018.208

Correspondence to: A. Denizli, Department of Chemistry, Hacettepe University, Ankara, Turkey. 


\section{INTRODUCTION}

Cyanide is an anionic chemical, which is formed $\mathrm{C}$ and $\mathrm{N}$ atoms by bonding 3 bounds. It can form complexes with various metals and cations. The salts formed with $\mathrm{Na}, \mathrm{K}, \mathrm{Ca}$ are highly toxic and can easily be dissolved in water. They release $\mathrm{HCN}$ by the action of acids. The most toxic of the cyanide varieties is free cyanide. It contains hydrogen cyanide $(\mathrm{HCN})$ and cyanide anion $(\mathrm{CN})$ which can be present both in gas form and in liquid form. The amount of cyanide in solution $\mathrm{pH} 11.0$ and above $99 \%$ is in the form $\mathrm{CN}$ but $\mathrm{pH} 7.0$ and below $99 \%$ is in the form of $\mathrm{HCN}$. In general terms cyanide has 2 basic sources. These are naturally occurring cyanides from various organisms and industrial sources of cyanide and its derivatives. Cyanides are found in nature more than 1000 plants as cyanogenic glycosides. Some of these are apricots, almonds, peaches, apples and chestnuts. The amygdalin compound in the nuclei of these plants. Amygdalin is digested in the body and transformed into HCN. Microbial cyanide production is also observed in the nature [1]. A large number of fungi belonging to produce cyanide. It is also known that cyanogen is produced by bacteria [2,3]. In cases where severe burn wounds are infected with $P$. aeruginosa, the production of cyanide can cause the patient to die [4]. The amount of cyanide produced by natural means is much lower than the amount of industrially produced cyanide. Mainly gold mining, synthetic rubber and production of some chemicals, leather, fertilizer, mouse and pesticide production areas. In addition, various cyanide compounds are used in photography, metallurgy and laboratory technics fields, leather hardening, electrolysis coating [5]. Cyanide performs its toxic effect by binding to ferric $\left(\mathrm{Fe}^{+3}\right)$ form of iron ion. It has been reported that many enzyme systems in the body are inactivated. The most important of these is the cytochrome oxidase system. The cytochrome oxidase system contains the cytochrome a-aa3 complex in electron transport. When cyanide binds to this enzyme complex, it inhibits electron transport and molecular oxygen is blocked. Oxidative metabolism and phosphorylation break down. From the standpoint of living life, cyanogen is of great importance in terms of low concentrations, especially microbial life. When found in sewage systems, the biological oxidation mechanism is prevented by affecting the activities of many types of bacteria in the negative direction. Therefore, it is important that they are kept at a minimum or never at all when they are discharged into natural waters [1].

Detoxification of wastewater containing cyanide is mostly carried out by chemical treatment methods. However, toxic compounds are formed as side products in chemical treatment methods. Various oxidation methods, ozonation, $\mathrm{Fe}-\mathrm{CN}$ precipitation and many other methods are used for cyanide detoxification as a chemical method [6]. In addition, the high cost of chemical methods as a disadvantage. Several methods have been studied which may be alternative to chemical methods. Molecular imprinting technology is one of them. Say and coworkers effectively removed cyanide from waste water with cyanide imprinted polymeric microbeads [7]. There are also studies using boron nitride nanotubes and zinc oxide nanomaterials [8].

Biological methods are an alternative potential approach to the conversion and destruction of other toxic by-products that can be formed by both cyanide and chemical treatment [9]. The first facility for the biodegradation of cyanide was established in the United States in the 1980s. In this plant, biological treatment is used effectively in daily life [6]. The history of studies on cyanide biofouling does not rely much on the past. Many effective microorganisms have been isolated as a result of these studies [10-12]. Just as it is the direct investigation of cyanide poisoning with these creatures, there are studies with enzymes purified from these organisms. Trichoderma spp. is one of the fungi used for this purpose [13-15]. The ability to provide cyanide degradation on aerobic conditions makes this fungus suitable for use in studies of biological treatment from waste water.

Parameters such as $\mathrm{pH}$, temperature, dissolved oxygen and toxic substances must be kept under control in order for the bacteria to carry out the treatment. Bioreactors, is an essential tool for the culturing of cells in a controlled and monitored environment. The bioreactor technology can optimize the nutrient and oxygen supply and also helps to control the removal of metabolic wastes. One of the important properties required for 
bioreactor matrices is the proper distribution of nutrients and oxygen.

Cryogel may be used as matrices that can provide high mass transfer which is a feature that should have the bioreactor. When the cryogels are synthesized, it is desirable that the solvent form ice crystals. For this reason, it is necessary to freeze the solvent at the temperature which the polymerization takes place. The melting of the ice crystals is provided after the polymerization process is complete. As a result, large pores connected to each other come into play [16]. Due to the large pore structure of cryogels, nutrients can be transported both by diffusion and conventionally. Becasue of this feature, cryogels are materials suitable for working with viscous media such as plasma and blood [17]. In addition, a cryogels can be used as a matrix in the detoxification process from waste waters having a large particle size range. PVA cryogels were used as carrier matrix for Thiobacillus denitrificus to use in denitrification studies [18]. Along with this, cryogels are materials that can be prepared in different sizes and shapes. There are studies in which the cryogels are synthesized in the form of membrane, column and bead [19].

In this study, we have combined the features of cryogels with Trichoderma spp. to create an alternative bioreactor bioadsorbent system to destruct cyanide ions from aqueous samples. The materials developed were characterized by swelling test and scanning electron microscopy measurements. Then, we evaluated the optimum cyanide removal conditions by varying affecting factors including $\mathrm{pH}$, temperature and initial cyanide concentration. As a result, the developed system and approach showed that the method proposed could be classified as a valuable alternative for cyanide removal from waste water samples and toxic substances [20-22].

\section{MATERIALS and METHODS}

\section{Materials}

2-Hydroxyethyl methacrylate (HEMA) used as monomerobtainedfromFluka(Buchs, Switzerland). Methylene bis-acrylamide (MBA) used as cross-linker, ammonium persulfate (APS), and $N, N, N, N^{\prime}$-tetramethylene diamine (TEMED) were obtained from Sigma (St. Louis, USA). Potassium cyanide $(\mathrm{KCN})$, potassium hydrogenphosphate $\left(\mathrm{K}_{2} \mathrm{HPO}_{4}\right)$, potassium dihydrogenphosphate $\left(\mathrm{KH}_{2} \mathrm{PO}_{4}\right)$ and Sabouraud-2\% dextrose broth were purchased from Merck (Darmstad, Germany). Cyanide analysis kit was purchased from ChemBio Laboratory Research (Istanbul, Turkey). All buffers and solutions were prepared with double distilled water from a Barnstead (Dubuque, IA, USA) ROpure LP $®$ reverse osmosis unit with a high flow cellulose acetate membrane (Barnstead D2731) followed by a Barnstead D3804 NANOpure ${ }^{\circledR}$ organic/colloid removal and ion exchange packed-bed system. All solutions and glassware used in this study were autoclaved at $120^{\circ} \mathrm{C}$ for $30 \mathrm{~min}$ and solutions were stored at $4^{\circ} \mathrm{C}$ until use.

\section{Trichoderma spp. Embedding Cryogels}

Isolated Trichoderma spp. were cultivated dextrose broth agar at $25^{\circ} \mathrm{C}$. Trichoderma spp. has been lyophilized which was cultivated in dextrose broth. The monomer (HEMA) and crosslinker (MBA) dissolved in deionized water $(15 \mathrm{~mL})$ to prepare the solution in concentration of $12 \%$ $(\mathrm{w} / \mathrm{v})$. After adding of freeze-dried Trichoderma spp. to previous solution, the initiator-activator pair, APS $(20 \mathrm{mg})$ and TEMED $(25 \mu \mathrm{l})$ were added to the final solution respectively and quickly poured between two glass panes with $1.0 \mathrm{~mm}$ thick spacer. This system was frozen at $-12^{\circ} \mathrm{C}$ and kept in frozen state for $24 \mathrm{~h}$. After that, it thawed at room temperature and glass pane were removed. They were subsequently cut into small circles (o.d. $1.0 \mathrm{~cm}$ ). For comparison purpose, the plain cryogels, Trichoderma spp.-free were synthesized as control group in the same method by skipping the addition step of freeze-dried Trichoderma spp. samples.

\section{Characterization Studies}

The cryogel samples were frozen at $-12^{\circ} \mathrm{C}$ and then lyophilized to prepare the microscopic analysis. Freeze dried cryogels were coated with gold/palladium (40/60) and viewed under scanning electron microscope (QUANTA 400F Field Emission SEM, Holland). Swelling tests were performed to determine the swelling degree and macroporosity percentage of the cryogels. The dry cryogel is weighed and then allowed to swell 
in deionized water for $2 \mathrm{~h}$ to calculate the swelling degree as following equilibrium.

Swelling Degree $=\left(\mathrm{W}_{\text {swe }}-\mathrm{W}_{\text {dry }}\right) / \mathrm{W}_{\text {swe }} \times 100 \%$ (eq 1)

Where, $W_{\text {swe }}$ and $W_{\text {dry }}$ are the weights $(g)$ of swollen and dry cryogels, respectively.

To determine the macroporosity percentage, the swollen cryogel was weighed at the first; then it was reweighed after squeezing by hand and the following equation was used to calculate the percentage.

$\begin{array}{ll}\text { Macroporosity } & \text { Percentage }=\quad\left(\mathrm{W}_{\mathrm{swe}}-\mathrm{W}_{\mathrm{sq}}\right) / \\ \mathrm{W}_{\mathrm{swe}} \times 100 \% & \end{array}$

Where, $\mathrm{W}_{\text {swe }}$ and $\mathrm{W}_{\text {dry }}$ are the weights ( $\mathrm{g}$ ) of swollen and squeezed cryogels, respectively.

\section{Cyanide Degradation Studies}

Experiments were carried out at various $\mathrm{pH}$ and temperature to determine the proper conditions for cyanide degradation with Trichoderma spp. embedded cryogels. Trichoderma spp. embedded cryogels (PHEMA-TrC) and control cryogels (PHEMA) were incubated in dextrose broth at $30^{\circ} \mathrm{C}$ for 3 days with aerobic conditions. Before starting the cyanide destruction studies, for each experiment, $10 \mathrm{~mL}$ of old medium, which the cryogels were incubated and $10 \mathrm{~mL}$ of fresh medium were added to $20 \mathrm{~mL}$ sterile glass bottles. Effect of $\mathrm{pH}$ was tested in the range of $5-8$ and effect of temperature tested at five different temperatures in the range of $20-40^{\circ} \mathrm{C}$. After optimization of these conditions, degradation experiments were carried out with cyanide containing solutions at different concentrations. Cyanide in all samples was analyzed by cyanide test kit according to the supplier's protocol.

\section{RESULTS and DISCUSSION}

\section{Characterization Studies}

As seen in the optical photographs, the colors of PHEMA and PHEMA-Trc cryogels are quite different due to the presence of Trichoderma spp. Therefore, Trichoderma spp. entrance into the cryogel structure could determined by naked eyes
(Figure 1). SEM images were examined to observe the pore sizes and morphological structures of the PHEMA and PHEMA-Trc cryogels as well. As can be seen, there are pores of about $100 \mu \mathrm{m}$ in diameter attached to each other in the cryogels. In case of embedding of Trichoderma spp., although a filamentous image have emerged with the addition of Trichoderma spp. to the structure, main structural feature including interconnected porous networks were remained (Figure 2).

Polymeric materials prepared to be used as bioreactor matrices are of great importance for determining whether they are suitable for this purpose. Swelling test is the one of the important analyses to describe structural flexibility and suitability as a bioadsorbent/bioreactor. From the swelling tests performed, the PHEMA and PHEMA-Trc cryogels have a swelling rate of about $590 \%$ and $600 \%$, respectively, while the swelling process was quickly completed in less than 1 minute (Figure 3). Extremely rapid swelling pointed out the highly porous nature of the cryogel, which are essential for efficient mass transfer and important for bioreactors. In addition, the percentage of macropores is about $75 \%$ for both systems, which designated that the required porosity for the bioreactor matrices is achieved.

\section{Effect of $\mathrm{pH}$}

Trichoderma destroys cyanide thanks to its cyanide catabolizing enzymes, which are rhodanase, cyanide hydratase and cyanoline synthase. Both fungi can produce and secrete these enzymes, so that the enzymes should have a certain $\mathrm{pH}$ value

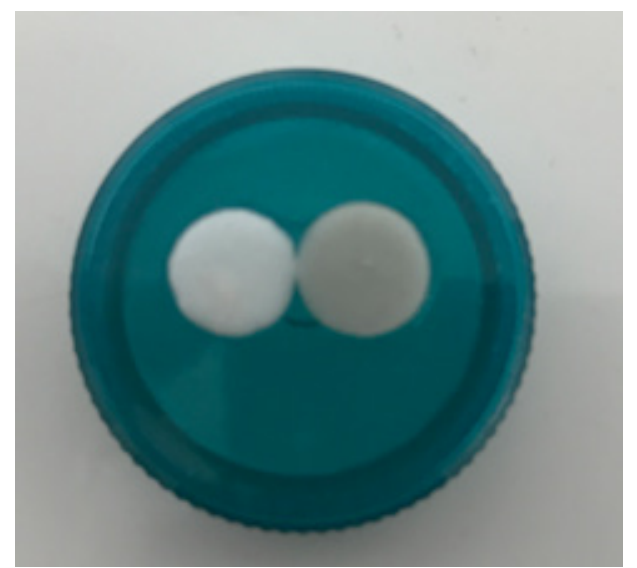

Figure 1. Optical image of PHEMA and PHEMA-Trc cryogels. 


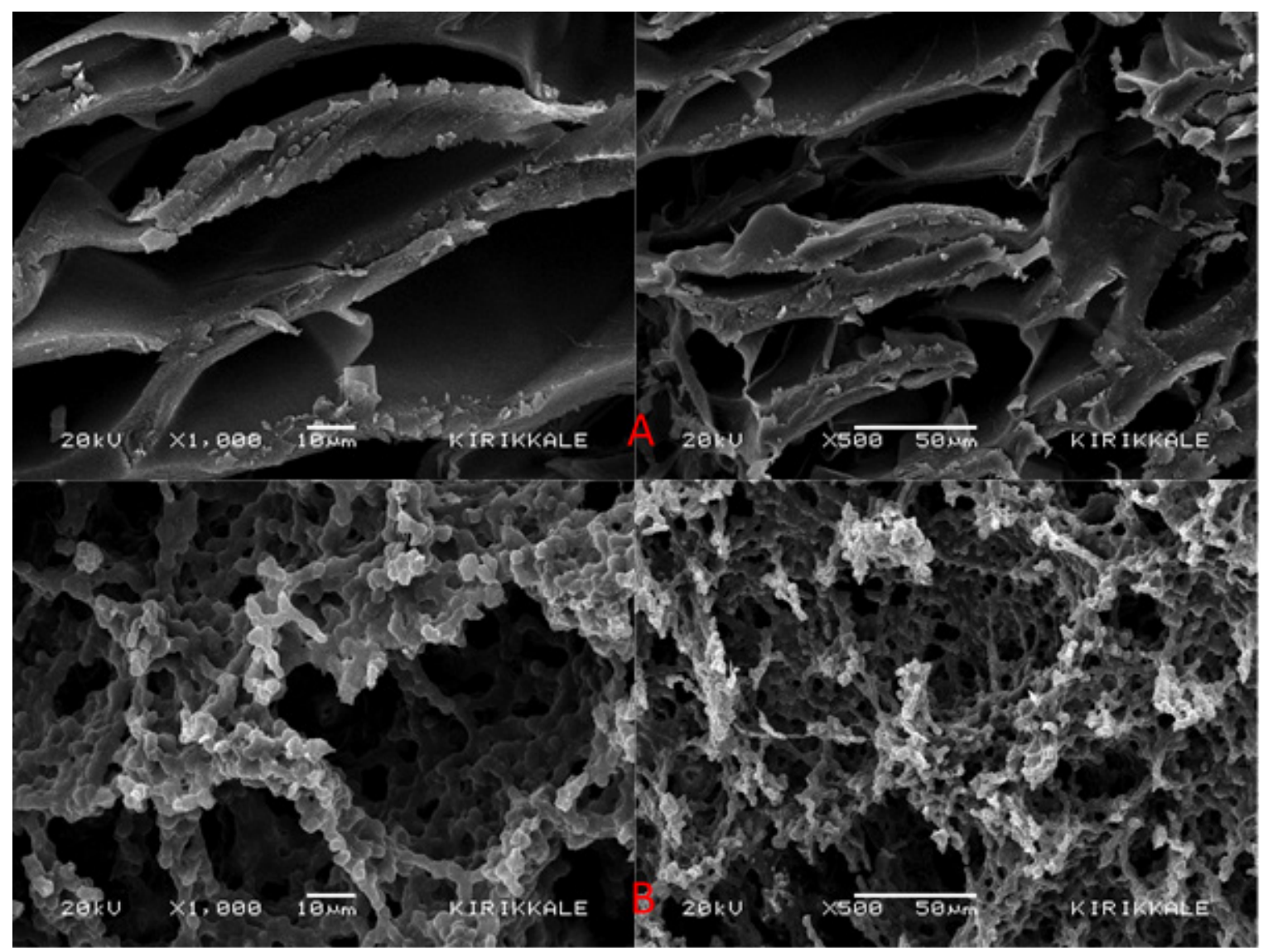

Figure 2. SEM image of PHEMA (A) and PHEMA-TrC (B) cryogels.

in order to capable to work at a proper conversion rates. Therefore, the experiments were carried out at seven different $\mathrm{pH}$ values between $\mathrm{pH} 5.0$ and 8.0. According to the obtained results, the highest detoxification was observed at $\mathrm{pH} 6.5$ whereas the lowest detoxification occurred at $\mathrm{pH}$ 8.0 (Figure 4). As seen in the figure, the variation of $\mathrm{pH}$ has no effect on the performance of the plain PHEMA cryogel. This result confirms that the embedding of Trichoderma spp. was achieved while remaining their cyanide detoxification

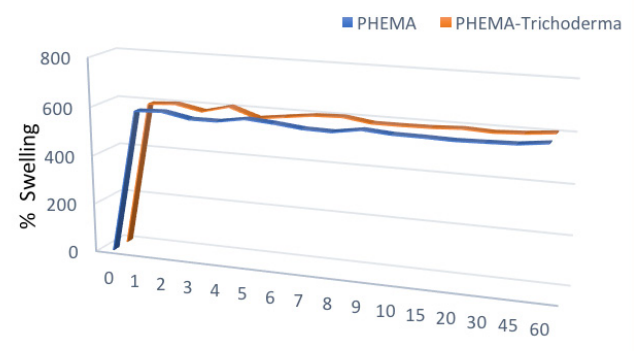

Time, $\min$.

Figure 3. Swelling rate of PHEMA and PHEMA-TrC cryogels. activities. Also, enzyme groups mentioned above have optimal structural and ionic conformation at $\mathrm{pH}$ 6.5. In this respect, the optimal pH value was accepted as 6.5 and kept as constant for further studies.

\section{Effect of Temperature}

Temperature plays an important role in the secretion and activity of enzymes as well as the $\mathrm{pH}$ value of the media. Therefore, the set of experiments to determine the most suitable

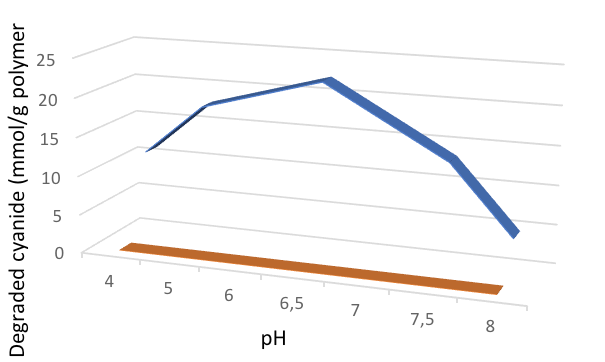

Figure 4. Effect of $\mathrm{pH}$ on degradation to PHEMA and PHEMA-Trc cryogel: initial cyanide concentration 20 ppm, $\mathrm{T}: 25^{\circ} \mathrm{C}$. 


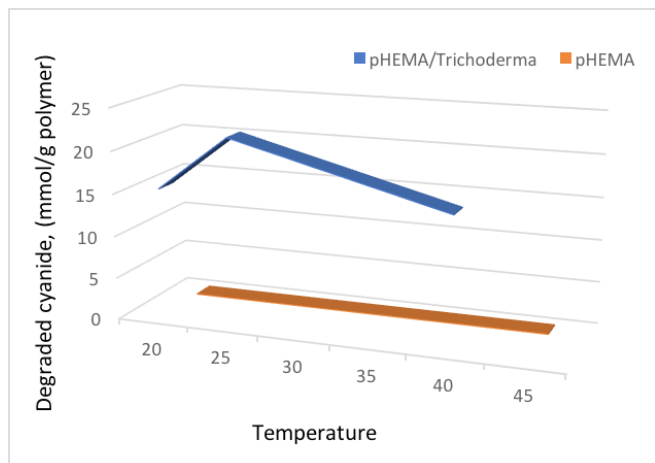

Figure 5. Effect of temperature on degradation to PHEMA and PHEMA-Trc cryogel: initial cyanide concentration 20 ppm, pH 6.5.

temperature for cyanide destruction were carried at five different temperature values as 20, 25, 30, 35 , and $40^{\circ} \mathrm{C}$ while keeping $\mathrm{pH}$ values around 6.5, which determined in the first step. As shown in Figure 5, the highest cyanide detoxification rate was determined at $25^{\circ} \mathrm{C}$. At lower and higher temperature values, cyanide destruction capacities gradually decreased. These decreases depended on the structural and conformational changes in enzymes structures as well as the solubility decrease of hydrogen cyanide ions by increasing temperature.

\section{Effect of Initial Concentration}

The initial analyte concentration is the one of most important parameters affecting on enzymatic activities. Therefore, a set of experiments was carried out at different initial cyanide concentration at optimal $\mathrm{pH}$ and temperature values as 6.5 and $25^{\circ} \mathrm{C}$, respectively. The results obtained from the experiments with different cyanide solutions in the range of 5-50 ppm cyanide showed an increase in cyanide degradation rate with increasing substrate concentration as

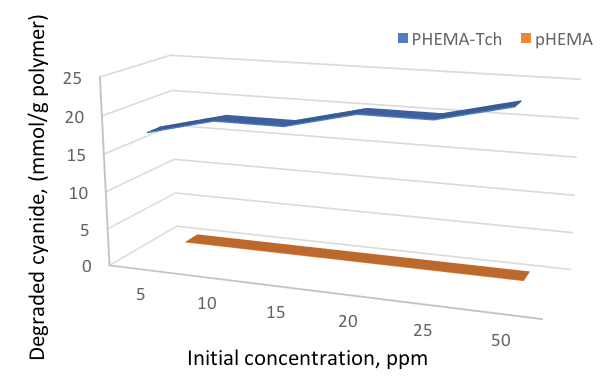

Figure 6. Effect of initial concentration on degradation to PHEMA and PHEMA-Trc cryogel: $\mathrm{pH} 6.5,25^{\circ} \mathrm{C}$. expected. Herein, the presence of substrate in higher amount enhanced the conversion rate and turnover of enzymes. The main reasons for these results are uncompleted occupation of enzymes with cyanide ions, a high turnover number of the enzymes, and convective substrate transport through cryogel network. In addition, the results showed a proper immobilization of Trichoderma $s p$. into cryogel network by proposed embedding strategy while remaining their enzymatic activities and combining their capabilities with an excellent structure features of cryogel. On the other side, we should note that there is no cyanide destruction ability was observed in the control group.

\section{CONCLUSION}

The aim of this study is to prepare cryogel membrane bioreactors by combining membrane systems and biological treatment. PHEMA cryogels with high pore structure have prepared durable materials which can achieve high flow resistance and mass transfer, wide areas where microorganisms can produce and which can control ambient conditions thanks to membrane structure [23-24]. This will facilitate the control of the parameters required for treatment. In addition, because of the shape that you have, the space will be reduced. Another advantage of having large pores is that they are very suitable for microbial growth. In this way, matrices were obtained to hold the cells together by taking of all the advantages of cryogels.

\section{References}

1. A. Çabuk, N. Kolonkaya, Toxicity and biological treatment of cyanide, J. Engi. Nat. Sci., 30 (2012) 2038.

2. C.J. Knowles, A.W. Bunch, Microbial cyanide metabolism, Adv. Microb. Physiol., 27 (1986) 73-111.

3. A.W.Bunch, C.J.Knowles, Production of the secondary metabolite cyanide by extracts of Chromobacterium violaceum, Microbiol., 128 (1982) 2675-2680.

4. W.B. Goldfarb, H. Margraf, Cyanide production by Pseudomonas aeruginosa, Ann. Surg., 165 (1967)104110

5. S.K. Dubey, D.S. Holmes, Biological cyanide destruction mediated by microorganisms, World. J. Microbiol. Biotechnol., 11 (1995) 257-65.

6. M.M. Botz, Overview of Cyanide Treament Methods, Mining Environmental Management, Mining Journal Ltd., London, UK., (2001) 28-30. 
7. R. Say, A. Ersöz, H. Türk, A. Denizli, Selective separation and preconcentration of cyanide by a column packed with cyanide-imprinted polymeric microbeads, Sep. Purif. Technol., 40 (2004) 9-14.

8. M. Pirmoradi, S. Hashemian, M.R. Shayesteh, Kinetics and thermodynamics of cyanide removal by ZnO@ $\mathrm{NiO}$ nanocrystals Trans. Nonferrous Met. Soc. China, 27 (2017) 1394-1403

9. C.J. Knowles, A.W. Bunch, Microbial Cyanide Metabolism, Adv. Microb. Physiol., 27 (1986) 73-111.

10. W.E. Fry, R.L. Millar, Cyanide Degradation by An Enzyme from Stemphylium loti, Arch. Biochem. Biophys, 151 (1972) 468-474

11. M.D. Adjei, Y. Ohta, Factors Affecting the Biodegradation of Cyanide by Burkholderia cepacia Strain C-3, J. Biosci. Bioeng., 89 (2000) 274-277.

12. A.U. Chaudhari, K.M. Kodam, Biodegradation of Thiocyanate Using Co-culture of Klebsiella pneumoniae and Ralstonia sp., Appl. Microbiol. and Biot., 85 (2010) 1167-1174.

13. M.I. Ezzi, J.M. Lynch, Cyanide Catabolyzing Enzymes in Trichoderma spp., Enzym. Microb. Technol., 31 (2002) 1042-1047.

14. M.I. Ezzi, J.A. Pascual, B.J. Gould, Characterization of the Rhodanese Enzyme in Trichoderma spp., Enzyme Microb. Tech., 32 (2003) 629-634.

15. I.M. Ezzi, J.M. Lynch, Biodegradation of Cyanide by Trichoderma spp. and Fusarium spp., Enzyme Microb. Technol., 36 (2005) 849-954.

16. V.I. Lozinsky, F.M. Plieva, Poly(vinyl alcohol) cryogels employed as matrices for cell immobilization. 3. Overview of recent research and developments, Enzyme Microb. Technol., 23 (1998) 227-242.
17. H. Alkan, N. Bereli, Z. Baysal, A. Denizli, Antibody purification with protein A attached supermacroporous poly (hydroxyethyl methacrylate) cryogel, Biochem. Eng. J., 45 (2009) 201-208.

18. Z. Zhang, Z. Lei, X. He, Z. Zhang, Y. Yang, N. Sugiura, Nitrate removal by Thiobacillus denitrificans immobilized on poly(vinyl alcohol) carriers, J. Hazard. Mater., 163 (2009) 109-1095.

19. F.M. Plieva, E. De Seta, I.Y. Galaev, B. Mattiasson, Macroporous elastic polyacrylamide monolith columns: processing under compression and scale up, Sep. Purif. Technol., 65 (2009) 110-116.

20. 20. R. Sombro, N. Memon, M.I. Bhanger, A. Denizli, Horserodish Peroxidase immobilized intoorganogelsilica composite for transformation of chlorophenols to biodegredable orcanic acids, Hacettepe J. Biol. Chem., 44 (2016) 351-364.

21. 21. K. Çetin, D. Türkmen, N. Sağlam, A. Denizli, Phanerochaete chrysosporium loaded cryogel column for biosorption of mercury (II) ions from aqueous solutions, Hacettepe J. Biol. Chem., 43 (2015) 225-233.

22. 22. E. Bayram, D. Türkmen, E. Yılmaz, I.Y. Galaev, A. Denizli, S. Bektaş, Poly (acrylamide-allyl glycidyl ether) cryogel as a novel stationary phase for chlorophenol adsorption, Hacettepe J. Biol. Chem., 36 (2008) 9-19.

23. 23. I. Koç, N. Bereli, G. Baydemir, I.Y. Galaev, A. Denizli, Syntgesis and characterization of macroporous poly (acrylamide-methacrylamido histidine) cryogels and their use in antibody purification, Hacettepe J. Biol. Chem., 36 (2008) 61-76.

24. 24. S. Utku, E. Yılmaz, D. Türkmen, B. Garipcan, R. Say, A. Denizli, lon imprinted thermo sensitive polymers for $\mathrm{Fe}$ (III) removal from human plasma, Hacettepe J. Biol. Chem., 36 (2008) 291-304. 